KATARZYNA SIERAKOWSKA

https://orcid.org/0000-0001-7998-7124

Instytut Historii im. Tadeusza Manteuffla Polskiej Akademii Nauk

\title{
KONIE I INNE ZWIERZĘTA NA ZIEMIACH POLSKICH W LATACH WIELKIEJ WOJNY
}

Zarys treści: $\mathrm{W}$ artykule podjęto próbę oceny zawartości materiałów pamiętnikarskich polskich autorów, dotyczacych I wojny światowej, pod kątem obecności w nich relacji o zwierzętach. Analizie poddano konteksty, w jakich pojawiają się w zapiskach czworonogi oraz relacje ludzi i zwierząt w szczególnym okresie wojny.

The content outline: The aim of the article is to analyze the content of diaries and memoirs by Polish authors dealing with World War I with regard to references to animals. The analysis concerns the contexts in which animals are mentioned and the mutual relationship between people and animals in extraordinary circumstances, in this case in times of war.

Słowa kluczowe: I wojna światowa, pamiętnikarstwo polskie XX w., animal studies

Keywords: World War I, Polish diary writing of the twentieth century, animal studies

W polskiej historiografii do tej pory nie poświęcano zbyt wiele uwagi zwierzętom. Zachęcona pojawianiem się coraz większej liczby opracowań dotyczących roli zwierząt, w tym i w Wielkiej Wojnie, postanowiłam przyjrzeć się polskim źródłom wspomnieniowym i dziennikom dotyczącym lat 1914-1918, by sprawdzić, czy pojawiają się w nich zwierzęta, jakie i w jakich kontekstach ${ }^{1}$. Uwzględniłam pamiętniki kobiet

${ }^{1} \mathrm{O}$ wykorzystywaniu źródeł pamiętnikarskich do badań nad I wojną światowa więcej zob. K. Sierakowska, Śmierć - wygnanie - głód w dokumentach osobistych. Ziemie polskie w latach Wielkiej Wojny 1914-1918, Warszawa 2015, s. 16-32; taż, Kobiecy 
i mężczyzn, cywilów i żołnierzy. Starałam się znaleźć źródła pochodzące z różnych zaborów. Trudniej było zachować parytet jeśli chodzi o pochodzenie społeczne autorów. Wszyscy piszaccy pochodzili z tzw. warstw oświeconych. Po lekturze okazało się, że w relacjach można znaleźć informacje o zwierzętach. Sa one jednak bardzo rozproszone. Najczęściej opisy zwierząt pojawiają się niejako w tle przedstawianych wypadków, zdarzeń, emocji. Znacznie rzadziej można spotkać zapiski poświęcone specjalnie zwierzętom. Niemniej i w tych różnych zdawałoby się marginalnych zdaniach i frazach da się odczytać stosunek ludzi do zwierząt, emocje, które im towarzysza. Punkt widzenia zwierząt możemy sobie tylko wyobrażać. Nie jest to jednak wyłącznie fantazjowanie - w wielu zapiskach reakcje zwierząt są opisywane, do historyka należy tu tylko konfrontacja tego, co zapisane $\mathrm{z}$ ustaleniami zoologów i innych specjalistów badajacych psychikę i zwierzęce reakcje na różne bodźce. Éric Baratay postuluje: „Opowiedzenie się po stronie zwierząt nie powinno zachęcać do tworzenia sztywnego obrazu, konstruowania nieruchomej historii, ponieważ nie takie było ich doświadczenie. Podobnie jak w wypadku ludzi, wiele zwierząt, które brały udział w walkach latem 1914, zginęło przed rokiem 1918, a nawet dużo wcześniej, a zwierzęcy wkład w wojnę bywa zróżnicowany zależnie od wytrzymałości zwierząt i stopnia awansu ich opiekunów"

Tekst ten traktuję jako rekonesans badawczy, zatem nie rości on sobie prawa do wyczerpania tematu, stanowi raczej próbę diagnozy stanu zawartości źródeł osobistych pod kątem obecności w nich zwierząt. Śródtytuły zamieszczone w tekście wskazują na kontekst, w jakim o zwierzętach jest w tego typu źródłach mowa. Osią refleksji czynię w nim relacje między ludźmi i zwierzętami w czasie szczególnym, jakim był okres I wojny światowej.

\section{Ucieczki}

Jak wiadomo, znaczne obszary ziem polskich stanowiły w latach Wielkiej Wojny teren przemarszu wojsk i/lub walki. Mieszkańcy często przerażeni pogłoskami, które do ich docierały o nadchodzącym froncie i zachowaniach żołnierzy lub przymuszani przez rozkazy

dokument osobisty z czasów I wojny światowej jako źródło historyczne, w: Człowiek, społeczeństwo, źródło. Studia dedykowane profesor Jadwidze Hoff, red. S. Kozak, D. Opaliński, J. Polaczek, S. Wieczorek, W. Zawitkowska, Rzeszów 2014, s. 537-545.

${ }^{2}$ É. Baratay, Zwierzęta w okopach. Zapomniane historie, tłum. B. Brzezicka, Gdańsk 2017, s. 75. 
władz - szykowali się do ucieczki. Zwykle odbywała się ona w sposób nieuporządkowany, szybko narastała panika. Towarzyszył jej strach uciekano, często nie mając przygotowanego żadnego planu ${ }^{3}$. W pośpiechu starano się ominąć tłok. Pamiętnikarz notował: „O jakimkolwiek choćby najmniejszym porządku nie było tam już mowy. Konie, wozy i automobile, a wśród tego luźne masy żołnierskie, idące z bronią lub bez broni, przedstawiały jedną wielką mieszaninę, spiesznym krokiem posuwająca się całą szerokością ulicy. Niekiedy porzucano pojedyncze wozy a nawet automobile, z których jeden wywrócono przed gmachem sejmowym. Wszystkich ogarnęło uczucie jakiejś paniki, wśród której ludzie byli w stanie Bóg wie co uczynić”․ Można sobie wyobrazić, że dla koni znalezienie się w tym chaotycznym tłumie musiało być równie, a może i bardziej przerażające niż dla ludzi. Nie dziwi więc, że: „Tłum ucieka główną arterią miasta, która jest właśnie Łyczaków - konie tratują ludzi - wozy najeżdżają na konie - światła gasna - piekło!”5. Tych wozów, stanowiących przecież ówcześnie główny środek transportu, było podczas ucieczek mnóstwo. Jak zauważył Ryszard Wojdaliński: „Przez główną ulicę miasta przeciagały niezliczone ilości furmanek i wozów drabiniastych, naładowanych ludźmi i wszelkiego rodzaju dobytkiem. Pędzono też bydło i konie"6. Panika towarzysząca ludziom musiała się zatem z pewnością udzielać także zwierzętom, zwłaszcza koniom. Jednak mimo tych ekstremalnych warunków ich właściciele nierzadko próbowali chronić swoje zwierzęta, zwłaszcza gdy były one żywicielami rodziny. Cytowany już Jan Włodkowski opisał scenę, w której furman nie chciał zaprzęgać koni, uznając, że są one zdrożone. Został pobity przez spanikowanego urzędnika, a następnie zmuszony do uległości za pomoca rewolweru ${ }^{7}$. Oddzielną opowieść należałoby poświęcić zwierzętom towarzyszącym ludziom podczas ewakuacji zwłaszcza z terenów wiejskich. Na ogół uciekinierzy starali się zabierać ze sobą krowy i konie - te drugie, by ciagnęły wóz i wiozły rodzinę, a krowy jako żywicielki. Wanda Zakrzewska opisując uciekinierów, którzy dotarli do Przemyśla, jako jedna z nielicznych zwróciła uwagę na związek emocjonalny właścicieli ze zwierzętami oraz na przywiązanie zwierząt do

${ }^{3}$ Więcej o ucieczkach zob. K. Sierakowska, Śmierć-wygnanie-głód..., s. 143 n.

${ }^{4}$ S. Srokowski, Z dni zawieruchy dziejowej 1914-1918, Kraków 1923, s. 30.

${ }_{5}$ Biblioteka Zakładu Narodowego im. Ossolińskich we Wrocławiu, akc. 142/81, J. Włodkowski, „Eldorado”. Wspomnienia z wojny 1914-1918, s. 11.

${ }_{6}$ BN, rkps akc. 10.560, R. Wojdaliński, Wspomnienia lubelskie 1914-1918, koniec lipca 1915 r., s. 28.

7 Biblioteka Zakładu Narodowego im. Ossolińskich we Wrocławiu, akc. 142/81, J. Włodkowski, „Eldorado”. Wspomnienia z wojny 1914-1918, dz. cyt., s. 11. 
miejsca, w którym żyły. Pisała: „Bo tam u wozu na żelaznym łańcuchu przypięta jedna krowina - żywicielka i przyjaciółka rodziny - pędzona przez kogoś ustaje również ze zmęczenia a ryczy z tęsknoty" ${ }^{\text {. Czasami }}$ zabierano też psa. „Widzimy w ścianach wąwozu wykopane jaskinie i postacie ludzkie krzątające się około małych ognisk rozłożonych pod kociołkami ze strawa - pisał Michał Kossakowski. - Do palików przywiązano krowy, na ziemi siedzi kilkoro dzieci, leżą psy"'. Co działo się z innymi zwierzętami, nie wiadomo. Czasami próbowały podążać za gospodarzami ${ }^{10}$, jednak czy długo dawały radę iść? Czy mogły się w tym tłumie nie zgubić? Na pewno przestraszone próbowały jakoś przetrwać czas walki. Z zachowanych zapisków można wnioskować, że niektóre były wyłapywane przez przechodzące wojska, które wykorzystywały je jako pożywienie.

\section{Rekwizycje}

Chyba najwięcej zapisków, zarówno cywilów, jak i żołnierzy, dotyczyło rekwizycji i mniej legalnych sposobów zabierania zwierząt. To dość oczywiste, ponieważ utrata zwierząt z gospodarstwa mogła sparaliżować pracę na roli, zmniejszyć dochody i w końcu znacznie pogorszyć sytuację aprowizacyjną tych, którym zwierzęta zabierano. Niemal od początku wojny pojawiają się doniesienia o rekwizycjach i zaborach zwierząt domowych, początkowo przede wszystkim koni, ale stopniowo też i innego inwentarza żywego. Ludwika Ostrowska z Maluszyna wielokrotnie umieszczała w swoim dzienniku zapiski o kolejnych rekwizycjach na rzecz różnych przychodzących oddziałów wojskowych, zarówno rosyjskich, jak i austriackich. I tak 23 VIII 1914 r. zanotowała: „Do nas przyjechało z Kurzelowa $\mathrm{w}$ niedzielę rano 5 uzbrojonych strzelców i rekwirowali 5 koni, które zabrali ze stajni cugowej, choć nie było wierzchowych. Mobilizacja zabrała, z folwarku Maluszyn i sąsiednich, 24, to już razem 29 - co będzie dalej?"11. Już 26 IX 1914 r. informowała

${ }^{8}$ W. Zakrzewska, Oblężenie Przemyśla. Rok 1914-1915. Z przeżytych dni, Lwów 1916 , s. 70.

${ }_{9}$ M. Kossakowski, Diariusz 21 maja - 31 sierpnia 1915, t. 1 cz. 1, red. M. Mądzik, przedm. i oprac. K. Latawiec, M. Korzeniowski, D. Tarasiuk, Lublin 2010, Zażółkiew, 11 VII 1915 r., niedziela, s. 127.

10 Tamże, Aleksandrów, 18 VI 1915 r., s. 51.

11 Trochę się zazdrości tym, co nie dożyli tych czasów... Dziennik Ludwiki Ostrowskiej z Maluszyna, oprac. J. Kita, P. Zawilski, Warszawa 2014 (Wielka Wojna Codzienność Niecodzienności, 1), 23 VIII 1914 r., s. 68. 
o zachowaniu kilkuset dragonów pruskich, którzy „usadowili się obozem na drodze od kancelarii do stajni, rozłożyli kuchnię polowa, zarżnęli młodego, wiosnowego byczka, zabrali sobie resztę naszych koni - piękna czwórkę gniadą i piątą kasztankę, ostatnią z drugiej czwórki - dali kwitek-świstek [...]. Teraz zostały nam z całej luźnej stajni trzy ogiery arabskie nie zaprzęgane i dwie klacze ze źrebiętami. Z dworu poprosili tylko o krowę dla 10 oficerów"12. Konie wykorzystywano przede wszystkim jako konie wierzchowe oraz pociagowe - do przewożenia sprzętu. Jak wskazują relacje, nie zwracano na ogół uwagi na potrzeby tych, którym je zabierano. Władysław Zahorski mieszkający w Wilnie relacjonował: „Dorożkarz z płaczem opowiadał mi, że wczoraj Niemcy zabrali u niego ostatnie 3-4 pudy owsa, także teraz nie ma czym nakarmić konia i musi go sprzedać, a koń ten przecie żywił jego z żoną i dwojgiem dzieci"13. Nie zwracano też specjalnie uwagi na stres zwierząt, którym się raczej nie przejmowano. Krowy, kury, gęsi zabierano na pokarm. „Wszystek nasz drób i świnie zabieraja. Krowy zarzynaja, a żądają masła świeżego co dzień i jajek na ciasto świąteczne"14. Można sobie tylko wyobrazić ganianie przez żołnierzy gdaczących kur i gęgających gęsi, a następnie ich zarzynanie, podobnie jak muczenie zarzynanych krów. Wydaje się jednak, że dla wszystkich oczywiste było, że inwentarz jest po to, aby służyć człowiekowi. Zarzynanie krów, kur czy gęsi nikogo nie bulwersowało. Nie ma też wzmianek o tym, aby żołnierze robili to w sposób przysparzający zwierzętom jakiegoś szczególnego bólu itp.

Zresztą te zapiski poświęcone rekwirowaniu zwierząt są na ogół dość lakoniczne, stwierdzające fakty. Znacznie rzadziej spotyka się informacje o emocjach towarzyszących właścicielom przy ich zabieraniu. Ludwika Ostrowska, jak można wyczytać z dziennika, ubolewała na utratą koni, zwłaszcza krwi arabskiej, ale raczej z powodów ekonomicznych. Julia Świtalska-Fularska też - jak pisała - „biedowała” bez koni. Swoje negocjacje $\mathrm{z}$ wojskami i emocje towarzyszace rekwizycji opisała ziemianka z okolic Radomska Aniela Belinowa: „Pierwszy ten oddział zabrał nam z pola 11 koni. Tadeusza $\mathrm{w}$ domu nie było, pojechał do Landrata do Radomska po pieniądze za konie. Sama więc poleciałam do Niemców, żeby bronić koni, razem z panem Sanieckim praktykantem, który mi ogromnie pomagał. Wymogliśmy na Niemcach, żeby nam w zamian choć parę koni zostawili. Zostawili więc kilka, ale w tym tylko trzy dobre,

12 Tamże, 26 IX 1914 r., s. 71-72.

${ }^{13}$ BN, III, rkps, mkf. 93010, 011, 012, W. Zahorski, Dziennik wielkiej wojny europejskiej, t. 1, 23 XII 1915 r.

14 Tamże, 22 XII 1914 r., s. 105. 
reszta zmarnowana. Zdobyliśmy kwitek, ale mało wart, gdyż nie podpisany przez oficera i bez stempla”15. I kilka dni później: „Ledwo upłynęło pół godziny po jego wyjściu, kiedy wpadają ułany. Pokręcili się po podwórzu i wywąchali nasze stajenne konie, schowane w komórce. Dwa najlepsze zabrali dając coś w rodzaju kwitu. Popłakałam się bardzo na widok, jak Karusię i druga doskonałą klacz z Cieszanowic wyprowadzaja" ${ }^{16}$. W przytaczanej relacji ziemianki dominuje ocena zwierzat z punktu widzenia ich przydatności ekonomicznej w gospodarce. Nie jest ona jednak pozbawiona szacunku, a nawet elementu przywiazania. Czasami żołnierze zabierali zwierzęta samowolnie, jak opisał jeden z relacjonujących: „Od ziemniaków do kury, od kury do świni, od świni do rabunku wszystkiego, co się zamarzy - nie ma ścisłego stopniowania - przejść łatwo" ${ }^{17}$. Ludność nierzadko się na tę samowolę skarżyła. Zwykle zapiski o rekwizycjach zwierząt są pozbawione emocji, to po prostu suche informacje mające pokazać spowodowaną wojną zmianę sytuacji ekonomicznej, wzrost lub spadek cen, wahania popytu i podaży ${ }^{18}$. Jednak wcale nierzadko zdarzają się dowody prawdziwego przywiązania do zwierząt. Jeden $\mathrm{z}$ takich przypadków odnotował w swoim dzienniku ksiądz Józef Rokoszny, uznając opowiedzianą mu scenę za „rozrzewniająca”. Stangret odchodzący do wojska „żegnał się z każdym swoim koniem i na pożegnanie wyrywał każdemu z ogona po włosku i zabrał ze soba!" 19 .

\section{Zwierzęta ofiary wojny}

Zwierzęta stawały się też ofiarami wojny. Wspomnieć tu należy o zwierzętach porzuconych przez właścicieli z powodu wojny, które nagle utraciły spokojny dach nad głową. Doświadczały nierzadko ogromnego huku - dźwięków, których do tej pory nie znały. „Chłopi ratowali dobytek, wynosząc przyodziewek i co popadło. Kule nie wybierały. Szły tak gęsto i tak zajadle kassały jak osy. Nie pytając czyśs wojak czy też nie. Rżenie koni, ryki krów, kwik świń mieszały się z potwornym hukiem

${ }_{15}$ Notatki z I wojny światowej Anieli Jałowieckiej-Belinowej, oprac. K. Studnicka-Mariańczyk, A.J. Zakrzewski, Radomsko 2014, 30 X 1914 r., s. 190.

16 Tamże, 2 XI 1914 r., s. 192.

17 Z krwawych dni..., s. 189.

18 Notatki z I wojny światowej..., 26 VIII 1914 r., s. 181, 9 X 1914 r., s. 189, 3 XI 1914 r., s. 193.

${ }_{19}$ Ks. J. Rokoszny, Diariusz Wielkiej Wojny 1914-1915, oprac., wstęp i przyp. W. Caban, M. Przeniosło, Kielce 1998, 6 VIII 1914 r., s. 14. 
armat, od których ziemia drżała. Kryte słomą chaty płonące wszystkie na raz w całej wiosce, przedstawiały pod wieczór, na tle lasu, z pękającymi $\mathrm{w}$ górze szrapnelami, potwornie wspaniałe, jakby nie $\mathrm{z}$ tego świata, widowisko pełne uroku i grozy. Ale urok pierzchał, gdy w tym piekle spostrzegło się ludzi. Wtedy stygła krew w żyłach. Co chwilę, któryś z naszych krzyczał. Słychać było »Ooooch...» i padał. Ginęli ludzie, dzieci i zwierzęta" ${ }^{20}$ - notował pamiętnikarz. Jeżeli zwierzęta przeżywały przejście frontu, to nierzadko trafiały na obcych ludzi, którzy próbowali je złapać.

Szczególną kategorię zwierząt ofiar wojny stanowia z pewnością konie, które rekwirowano niemal bez przerwy. Szybko zmieniały dotychczasowe życie: traciły właścicieli, stajnie, musiały przyzwyczajać się do warunków frontowych: wykonywania bardzo ciężkiej pracy, np. ciagania dział, długich marszów, braku snu ${ }^{21}$. Rotacja tych armijnych zwierząt była duża. Ludwika Ostrowska zanotowała: „Te pozabierane konie padają już po drodze. Będą brać inne”22. I rzeczywiście na ogół, gdy konie nie dawały rady, zostawiano je lub sprzedawano za bezcen, a brano inne. Zwierzęta, które przychodziły z wojny, były często bardzo osłabione. Trudno jednak byłoby powiedzieć, że wojsko o swoje konie nie dbało. W Maluszynie funkcjonował przez jakiś czas lazaret dla koni „kulawych i chorych, które stoja we wszystkich naszych budynkach i w Pukarz[o]wie" - pisała Ludwika Ostrowska ${ }^{23}$. A musiało ich być sporo. Niemal po każdej bitwie, w której ginęli zarówno żołnierze, jak i konie, zostawały nie tylko, jak pisali pamiętnikarze, „stosy trupów” tak ludzkich, jak i końskich, ale również rzesze rannych. Maria Stecka przytaczała opis pobojowiska nad Wereszyca, gdzie „były też miejsca całkiem grząskie od krwi. Wśród tego włóczyły się pokaleczone konie"24. Gdy rany były zbyt głębokie zwierzęta zabijano, skracając im w ten sposób cierpienia. Tak zrobił pewien niemiecki oficer $\mathrm{w}$ Wilnie poproszony przez przechodniów, którzy po eksplozji zobaczyli konia „z urwaną nogą tylną”25. Konie, które dla wojska stawały się nieprzydatne, oddawano chłopom. Wielu z nich wykorzystywało te „chabety” z braku innych zwierząt. Niektórzy robili na tym dobry interes, sprzedając je innym potrzebującym.

\footnotetext{
${ }^{20}$ A.L. Kornik, Mój batalion: ... my, byli legioniści!, Kraków 1937.

${ }^{21}$ Więcej pisał o tym É. Baratay, dz. cyt., s. 75 n.

${ }^{22}$ Trochę się zazdrości..., 3 X 1914 r., s. 78.

${ }^{23}$ Tamże, 2 III 1915 r., s. 111.

${ }^{24}$ Biblioteka Zakładu Narodowego im. Ossolińskich we Wrocławiu, akc. 128/63, M. Stecka, Dzienniki 19 VIII $1914-10$ V 1915, s. 53.

${ }_{25}$ M. Brensztejn, Dziennik 1915-1918, cz. 1: Rok 1915 i 1916, oprac., wstęp i przyp. M. i M. Przeniosło, Kielce 2015, 5/18 IX 1915 r., s. 36.
} 
W przeciwieństwie do ludzi, których zwykle dość szybko po zakończeniu bitwy grzebano, konie często pozostawiano niepochowane, można powiedzieć jako widomy znak wojny. Henryk Pietrzak pisał: „Po drodze spotykamy padłe konie, roznoszące wstrętną woń dookoła" ${ }^{26}$. Podobnie inni pamiętnikarze wielokrotnie wspominają widok napuchniętych trupów końskich leżących na polach bitew i wzdłuż dróg ${ }^{27}$.

We wspomnieniach pojawiają się też wzmianki o psach. Trudno je jednoznacznie zaliczyć do ofiar wojny, choć z pewnościa wiele z nich gubiło podczas działań wojennych swoich właścicieli. Próbowały jednak jakoś przeżyć. Niemieckie władze okupacyjne wydawały zarządzenia dotyczące bezpańskich zwierząt, co wskazuje, że włóczące się psy nie były rzadkim widokiem. Trudno ocenić, czy liczba bezpańskich psów zwiększyła się podczas wojny (choć przypuszczalnie tak), a jeżeli tak, to o ile. Niezależnie jednak od liczb problem istniał. Michał Brensztejn notował w swoim dzienniku kilkakrotnie, jakie działania podejmowały władze niemieckie, aby walczyć z bezpańskimi psami. Nakazywano łapanie i zabijanie psów „włóczących się bez kagańca i smyczy”28. Podobne doniesienia pojawiają się w dzienniku przemyskim Heleny z Seifertów Jabłońskiej. I choć zapiski Brensztejna wskazują też, że walka ta nie była zdaniem władz niemieckich specjalnie skuteczna, za co zreszta władzom Wilna groziły grzywny, to jednak pamiętnikarz podaje, że od wkroczenia Niemców do 9 XII 1915 r. zabito w Wilnie 2978 psów ${ }^{29}$. Dysponujemy również świadectwami wskazujaccymi na duże przywiązanie do domowych psów. Na przykład Helena z Seifertów Jabłońska opisuje, jak rezygnowała z mięsa, aby pies miał co jeśćc ${ }^{30}$. Jej późniejsze zapiski wskazują też, jak trudno było zwierzęciu przystosować się do szybko pogarszającej się sytuacji żywnościowej w obleganym mieście i jak bardzo właścicielka martwiła się brakiem możliwości kupienia mięsa dla swojego ulubieńca. Czytamy: „Miko jeszcze nie pojął, że nie ma, głodny, łapką mnie skrobie, a nie chce jeść chleba ni mamałygi, ledwie słoninę zliże, a mnie łzy w oczach staja. A choćby koronę dziennie dałabym, aby nie zdechł"31. Szczegółowo przedstawia też perypetie związane z uciecz-

${ }^{26}$ H. Pietrzak, Sześć lat wojny (pamiętnik polskiego żotnierza), Łódź 1936, s. 21.

${ }^{27}$ Na przykład BN, III, rkps, mkf. 93010, 011, 012, W. Zahorski, Dziennik wielkiej wojny europejskiej, t. 1, 6 X 1915 r.: „Po drogach leżą setki padłych koni i nikt ich nie grzebie...".

${ }^{28}$ M. Brensztejn, dz. cyt., 11 XI 1915 r., s. 56.

29 Tamże, 9 XII 1915 r., s. 65.

${ }^{30}$ H. z Seifertów Jabłońska, Dziennik z oblężonego Przemyśla 1914-1915, wstęp, przyp. i oprac. S. Stępień, Przemyśl 2018, s. 98: „Byle Miko miał, mnie wystarczy”.

${ }^{31}$ Tamże, 26 XI 1914 r., s. 243. 
kami Miko. Świadczy to o dużym przywiązaniu autorki do zwierzęcia i o prawdziwej trosce o jego los. Dodać warto, że ucieczki te, które zresztą zakończyły się ostatecznie zaginięciem psa, mogły być związane $\mathrm{z}$ okresem rui u suk, a ówcześnie nie praktykowano sterylizacji zwierząt. Pies Heleny Jabłońskiej uciekał dwa razy i po kilku tygodniach się znajdował, za trzecim razem uciekł i już nie udało się go odnaleźć. Autorka chodziła po całym mieście, dawała ogłoszenia do miejscowych gazet, wypytywała hycla i chodziła do niego, pytając, czy nie znalazł jej psa. Wyznaczyła nawet nagrodę. Tak o tym pisała: „Cała noc oka nie zmrużyłam nadsłuchując, czy Miko się nie zgłosi. Stróżowi dałam koronę, aby do bramy wychodził i przed 12 nie zamykał. Wyznaczyłam Włochom 5 koron nagrody, ale Mika nie ma. Nie wyobrażam sobie, aby mnie jeszcze coś tak bardzo dotknąć mogło" 32 .

\section{Zwierzęta na froncie}

Relacje z pobytu zwierząt na froncie nie sa w polskich pamiętnikach zbyt częste. Jeżeli już się pojawiaja, to w znacznej większości dotyczą koni. Dość dobrze natomiast opisano służbę zwierząt w armii w pamiętnikach brytyjskich, francuskich i niemieckich. Bardzo dużo ciekawych ustaleń zawiera książka Érica Barataya. Autor pisze nie tylko o koniach, ale również mułach, osłach, psach i gołębiach. Wskazuje, że zwierzęta nie tylko doświadczały na froncie podobnych uczuć jak ludzie: strachu, złości, apatii itp. Musiały się przyzwyczaić, podobnie jak ludzie, do odgłosów wojny. Zwykle reagowały na odgłosy strzałów i wybuchów, jak klacz Kazimierza Filara, która „za każdym strzałem troszkę podrygiwała, jak się później okazało, baliśmy się na darmo, bo się ani mnie, ani koniowi nic nie stało"33. Józef Iwicki pisząc o walkach w Belgii, notował, iż: „Huk jest czasem tak straszny, że konie niektóre dębem staja, a bydło rozbiega się na wszystkie strony"34. Konie odczuwały też czasem strach, gdy zobaczyły lub wyczuły nieznane im osoby. Ksiądz Kazimierz Nowina-Konopka, troskliwy opiekun koni, kilkukrotnie opisywał w swoich wspomnieniach takie reakcje u konia, np.: „Wtem czuję, że koń się coś niepokoi, wilki czy co? Wbijam oczy

32 Tamże, 14 X 1914 r., s. 160.

33 Śmieszne to życie! Ale go żal... Dzienniki Kazimierza Filara, oprac. P. Szlanta, współpr. L. Boryczko, Warszawa 2018, cz. 1, 12 X 1914 r., s. 105.

${ }^{34}$ J. Iwicki, Z myśla o Niepodlegtej... Listy Polaka, żotnierza armii niemieckiej, z okopów I wojny światowej (1914-1918), wybór, wstęp i oprac. A. Juzwenko, Wrocław 1978, blisko Woumen pod Dixmuede, 25 X 1914 r., s. 26. 
w ciemną przestrzeń, widzę, że obok mnie sterczy jakiś czarny złowrogi kontur wysokiej sosny. Koń nagle rzuca mi się szczupakiem w bok, tak że omal nie strącił mnie z siodła i zaczyna ponosić...” lub „Koń nieco rzucał kilka razy niespokojnie, bo szli jacyś ludzie. Pewnie wojskowi”35. Zwierzęta cierpiały też okresowo z powodu niedożywienia lub niewłaściwej karmy. Polscy autorzy również potwierdzaja, że zdobywanie żywności dla zwierząt, choć pozostające w tyle za koniecznością zorganizowania pokarmu dla ludzi, stanowiło przedmiot ich zabiegów. Najwięcej wzmianek dotyczy koni, które zwłaszcza legionowej kawalerii były bardzo potrzebne. Szczepan Pilecki, w czasie wojny student prawa w Krakowie, zauważał pewną wspólnotę wojennego losu, pisząc, że podczas długotrwałych marszów i noclegów pod gołym niebem mokli zarówno ludzie, jak i konie ${ }^{36}$. W innym miejscu opisywał zmęczenie zwierząt: „Do końca naszego marszu do Monte Rover (Monte Rovere płaskowyż $1250 \mathrm{~m}$ n.p.m.) nie mieliśmy już nawet $6-8 \mathrm{~km}-$ konie i ludzie byli skonani setnie" ${ }^{37}$. O zmęczeniu pisał też walczący w ck armii Kazimierz Filar - gdy konie były zdrożone jeźdźcy szli na piechotę $e^{38}$. Wydaje się, że wielokilometrowe marsze, na które narzekali żołnierze, dawały się nierzadko równie mocno we znaki koniom, które czasami nie były rozsiodływane nawet przez 48 i więcej godzin. Podczas wspólnej walki nawiązywały się też relacje między żołnierzami i ich końmi. Sporo zapisków dowodzi, że strata konia była często dla żołnierza powodem do smutku. Wiele miejsca poświęcano też opisom zabiegów związanych z wyborem koni. Zwykle żołnierze zmieniali wierzchowca przynajmniej kilkukrotnie. Czasem z powodu, jak wyżej napisano, śmierci, czasem choroby czy po prostu dlatego, że zwierzę słabo sprawowało się na froncie. Kazimierz Filar wymienił konia, ponieważ zrobiły mu się rany od uprzęży, ale nowy jego zdaniem zupełnie się nie nadawał: „ani chodzić nie umie, ani żadnej inteligencji nie posiada" ${ }^{39}$. Następny natomiast był dokonały i autor pragną: „gdyby mi ta kobyła do końca wojny wytrzymała, bo dobrze chodzi i ładna jest" 40 .

Bez koni na froncie obejść się nie mogła nie tylko kawaleria. Używano ich do transportu niemal wszystkiego. Przede wszystkim do

${ }^{35}$ K. Nowina-Konopka, Wspomnienia wojenne 1915-1920, [oprac., wstęp i przyp. J. Humeński, M. Dębowska], Kraków 2011, s. 66-67.

${ }^{36}$ S. Pilecki, Na frontach I wojny światowej. Pamiętniki, wstęp R. Skapski, Warszawa 2015, 12 IV 1915 r., s. 52.

37 Tamże, 9 IV 1916 r., s. 87.

38 Śmieszne to życie!..., cz. 1, 24 VIII 1914 r., s. 48.

39 Tamże, 7 X 1914 r., s. 94.

40 Tamże, 9 X 1914 r., s. 100. 
przewożenia żywności: „wozy z prowiantem, beczki z woda, z sianem, podwody z worami maki [...] zapasy siana, kuchnie polowe, toboły..." wymieniał Cezary Jellenta ${ }^{41}$. Wykorzystywano je również do przewożenia rannych. Transportowały też działa. Ich pomoc była szczególnie niezbędna w trudnych warunkach. To one wciagały armaty w Alpach. Aby mogły skutecznie wykonywać tę pracę, należało je dobrać w odpowiednie zaprzęgi, co wymagało, jak sugeruja wspominający, niemało czasu. Przebywający na froncie w okolicach Trydentu Szczepan Pilecki notował: „Byłem cały dzień wczoraj zajęty zestawianiem zaprzęgów, dopasowywaniem uprzęży itd. Pod wieczór zrobiliśmy pierwsze próby, szło jako tako" ${ }^{42}$. Konie pracowały w nocy, ciagnąc działa po wąskich, górskich drogach ${ }^{43}$. Po powrocie mogły odpocząc w stajniach, które starano się robić wygodne, aby zrekompensować zwierzętom wielki wysiłek. Starano się też dobrze je odżywiać, co w tych ekstremalnych warunkach było szczególnie trudne ze względu na ograniczone możliwości dowozu paszy.

\section{Gdyby nie one - jak byśmy przetrwali}

Wspomnienia i dzienniki zawieraja znacznie mniej informacji o innych zwierzętach niż konie. Jeśli już to najczęściej pojawiają się wzmianki o trzodzie chlewnej i krowach - jako o źródłach pożywienia. Aniela Belinowa kilkakrotnie notowała informacje o sprzedaży trzody chlewnej i o cenie, jaką można było uzyskać. Pisała również o uboju zwierząt. Wspominała o tym też Ludwika Ostrowska. Podobnie jak inni niepokoiła się przede wszystkim tym, że zwierząt może nie starczyć i wtedy zabraknie jedzenia. Krowy ceniono także ze względu na mleko. Towarzyszyły one uciekinierom, ale też przemieszczającym się armiom. Ksiądz Nowina-Konopka, który zajmował się m.in. aprowizacja, z zadowoleniem przyjął możliwość hodowania 2 krów mlecznych i notował: „Żołnierze byli radzi, bo nie musieli tego mięsa na plecach dźwigać i oficerowie nie potrzebowali tych rezerwowych porcji kontrolować, a ja miałem codziennie do 10 litrów mleka dla maneży. Odtąd czarna kawa zbielała, pokazało się świeże masło do rannej kawy" ${ }^{4}$. Źródła osobiste wyraźnie wskazuja, że krowy uznawano za żywicielki

${ }^{41}$ C. Jellenta, Wielki zmierzch. Pamiętnik, przedm. R. Taborski, Warszawa 1985, s. 30 .

${ }^{42}$ S. Pilecki, dz. cyt., 9 IV 1916 r., s. 86.

${ }_{43}$ Tamże.

${ }^{44}$ K. Nowina-Konopka, dz. cyt., s. 48. 
i rodzinny dobytek. Wśród opisów uciekinierów niejednokrotnie pojawia się opis krowy żywicielki. Pamiętnikarze wspominają fury i przytroczone do nich wychudzone krowy, obozowiska uciekinierów, w których wraz z ludźmi mieszkaja krowy i psy. Ponieważ kuchnie polowe nie zawsze dojeżdżały na czas żołnierze musieli jakoś sobie radzić z zaspokajaniem głodu. Czasem, jak wspomina np. Ludwika Ostrowska, rekwizycje odbywały się z sposób przepisowy, nierzadko jednak żołnierze uciekali się do zwyczajnego rabunku. Michał Römer notował w dzienniku: „Nazajutrz rano wieś już była do niepoznania; znikły świnie, kury, gęsi, chłopi siedzieli po chatach posępni, oburzeni, przejęci zgroza; już nie traktowali nas niczym, ale wszystkie resztki czego mieli, pochowali i już nawet sprzedać nie chcieli. Natomiast w obozowiskach niemieckich smażono dokoła świninę, pieczono gęsi, stały całe sznury powiązanych owiec, na wozach leżały powiązane gęsi, pełno było widać świń czekających swego losu, uwiązanych do jakiegoś kołka lub płotu"45.

Wraz z przedłużająca się wojną pogarszała się, zwłaszcza w miastach, sytuacja aprowizacyjna. I na wsiach też nie zawsze było lekko. Jednak mimo że Ludwika Ostrowska pisała wiosną 1915 r.: „Zjedliśmy wczoraj ostatniego indora (jednego i 4 indyczki próbujemy zachować na rozmnożenie)”, to jednak zaraz dodawała: „mamy w lodowni ostatniego kaczora, w kurniku jeszcze kilkadziesiąt kur i piętnaście prosiaków. Wszystko pod strachem, że nowa fala wszystko zabierze", zatem jakieś rezerwy zostawały ${ }^{46}$. Oczywiście znacznie gorzej wyglądała sytuacji w gospodarstwach, przez które przeszedł front. W miastach jednak coraz częściej żadnych rezerw już nie było. Władze imały się więc różnych sposobów, by zaspokajać potrzeby żywnościowe mieszkańców. Początkowo, gdy to było możliwe, do konsumpcji przeznaczano mięso końskie, później także psie. Helena Jabłońska i Wanda Zakrzewska - obie relacjonujące życie w oblężonym Przemyślu - wspominały brak mięsa i jedzenie koniny. Pierwsza dodawała, że dla cywilów dostępne były tylko gorsze części ${ }^{47}$. Druga pisała o powszechności jedzenia końskiego mięsa ${ }^{48}$. W Warszawie otwarto w 1916 r. na Pradze psią rzeźnię, o czym informowano mieszkańców: „Wobec coraz większego zastosowywania mięsa psiego, jako codziennego pokarmu dla mieszkańców naszego miasta, postanowiono zorganizować stały nadzór nad biciem tego mięsa i w tym celu wyznaczono specjalną rzeźnię na Pradze, gdzie mięso zaopatrywane będzie

${ }^{45}$ M. Römer, Dzienniki legionowe I. 18.VII.1915-24.II.1916, przyg. do dr. Z. Solak, współpr. J.T. Nowak, A. Garlej-Solak, Kraków 2008, 5 XII 1915 r., s. 312.

${ }^{46}$ Trochę się zazdrości..., 9 IV 1915 r., s. 118.

${ }^{47}$ H. z Seifertów Jabłońska, dz. cyt., 16 XII 1914 r., s. 105.

${ }^{48}$ W. Zakrzewska, dz. cyt., s. 100. 
w pieczęć urzędu weterynaryjnego" ${ }^{49}$. O popycie na przetwory z mięsa psiego świadczy też zapisek mieszkańca stolicy Tadeusza Bablewskiego: „Codziennie przechodziłem koło sklepu na rogu Brackiej i Placu Trzech Krzyży, gdzie dziś mieści się sklep »Desy«. Stał tam zawsze długi »ogonek« ludzi. Czekali na wyroby z psiego mięsa, zwłaszcza na czerwone kiełbaski”" ${ }^{0}$. Inną alternatywa, do której zresztą zachęcano na łamach gazet, była hodowla królików, które - jak pisała Zofia Nałkowska „powszechnie teraz dla drożyzny mięsa sa hodowane" ${ }^{51}$. Pisarka mieszkająca $\mathrm{z}$ matką i siostrą hodowała również 2 króliki na mięso. Maria Lubomirska z kolei w 1916 r. zaczęła hodować przy pałacyku na Frascati w Warszawie świnie, w obawie przed całkowitym brakiem mięsa. Świnie ratowały też od głodu ewakuowanych. Stanisław Bobrowski wyjeżdżający z rodziną do Wiednia pisał: „Towarzyszyły nam w drodze trzy wagon towarowe z prowiantem i kilkudziesięcioma niedotuczonymi prosiakami. Stały się one podstawą naszego wyżywienia w Wiedniu, który pościł ze względu na potrzeby aprowizacyjne armii. Jedliśmy w kółko znakomity krupnik na wędzonce wieprzowej, który po pewnym czasie tak mi obrzydł, że dziś jeszcze ciarki mnie nachodzą na widok wędzonego mięsa"52.

\section{Podsumowanie}

Teksty pamiętnikarskie z ziem polskich dotyczące Wielkiej Wojny zawieraja, co podkreślę raz jeszcze, sporo rozproszonych zapisków dotyczących zwierząt. Najwięcej opisów dotyczy koni - piszą o nich zarówno cywile, jak i żołnierze. Dostrzegaja niezbędność tych zwierząt tak na froncie, jak i na zapleczu. Konie służyły jako zwierzęta pociagowe, ale również, gdy sytuacja żywnościowa się pogarszała, spożywano ich mięso. Zapiski potwierdzają formułowaną wielokrotnie tezę o w zasadzie niekończaccym się zapotrzebowaniu na konie podczas wojny. Dają również możliwość odpowiedzi na pytanie o reakcje tych zwierząt na wojnę i na zmianę ich sytuacji. W zapiskach można też spotkać sporo informacji dotyczacych innych zwierząt gospodarskich - bydła, trzody chlewnej czy drobiu. Na ogół pojawiają się one w kontekście rekwizycji

49 „Echo Pragi” 1916, nr 12, s. 97.

50 T. Bąblewski, U progu niepodległości. Wspomnienia z lat 1915-1921, Warszawa 1996, s. 105.

${ }^{51}$ Z. Nałkowska, Dzienniki, t. 2: 1909-1917, Warszawa 1976, Górki, 18 VII 1916 r., s. 435 .

${ }^{52}$ BN, rkps akc. 10898, S. Bobrowski, Wspomnienia, s. 7. 
oraz jako źródło pożywienia: mleka, jaj, mięsa. Właściciele nie zajmują się ich psychicznym dobrostanem, nie ma też jednak oznak okrutnego traktowania. Może to wynikać ze specyfiki analizowanych źródeł. Pisali je bowiem raczej ludzie należący do warstw oświeconych, często właściciele majątków ziemskich. Warto też jednak dostrzec, że zwierzęta gospodarcze również dla chłopów miały niebagatelne znaczenie. Wojna ze względu na rekwizycje, niedobory itd. pozwala, jak sądzę, w jeszcze większym stopniu docenić ich niezbędność dla człowieka. Pozycja zwierząt $\mathrm{w}$ relacji z ludźmi wydaje się ustalona - służą one człowiekowi, który o nie dba. Jednak wojna z powodów, o których wyżej była już mowa, zmusza nierzadko do większej troski o zwierzęta, do szukania sposobów przetrwania nie tylko dla ludzi, ale i dla nich. Można więc postawić tezę, że zwierzęta, zwłaszcza gospodarskie, nabierają w okresie wojennym dodatkowego znaczenia, nierzadko bowiem to od nich zależy przetrwanie człowieka.

Najrzadziej w literaturze pamiętnikarskiej dotyczącej lat Wielkiej Wojny można znaleźć wzmianki o zwierzętach hodowanych w domu dla przyjemności właścicieli. Podczas lektury udało mi się znaleźć jedynie jedną relację na ten temat, czyli przypadek Heleny Jabłońskiej z psem Miko. Wydaje się, że trzymanie zwierząt $\mathrm{w}$ domu w mieście nie było w latach przed I wojną światową szczególnie popularne.

$\mathrm{W}$ przeciwieństwie do relacji $\mathrm{z}$ tego okresu z zachodu Europy nie udało mi się znaleźć wzmianek o hodowaniu zwierząt takich jak psy czy koty przy wojsku. Być może wynikało to z innej specyfiki frontu wschodniego i zachodniego. Przebywanie przez długi czas w jednym miejscu, jak miało to miejsce podczas wojny pozycyjnej, mogło sprzyjać przetrzymywaniu zwierząt w okopach.

Dobra charakterystykę relacji ludzi do zwierząt, prawdziwą też jak sądzę w kontekście polskim, zawarł w swoich rozważaniach cytowany już Éric Baratay: „Mieszczanie żyli z dala od nich i traktowali je obojętnie. $\mathrm{Z}$ kolei relacje wieśniaków ze zwierzętami były bliskie, ale surowe..." ${ }^{53}$.

\section{Bibliografia}

Baratay É., Zwierzęta w okopach. Zapomniane historie, tłum. B. Brzezicka, Gdańsk 2017.

Sierakowska K., Kobiecy dokument osobisty z czasów I wojny światowej jako źródło historyczne, w: Człowiek, społeczeństwo, źródło. Studia dedykowane

53 É. Baratay, dz. cyt., s. 137. 
profesor Jadwidze Hoff, red. S. Kozak, D. Opaliński, J. Polaczek, S. Wieczorek, W. Zawitkowska, Rzeszów 2014, s. 537-545.

Sierakowska K., Śmierć - wygnanie - gtód w dokumentach osobistych. Ziemie polskie w latach Wielkiej Wojny 1914-1918, Warszawa 2015.

Katarzyna Sierakowska

Horses and other animals in the Polish lands during the Great War (Summary)

Source documents in the form of diaries and memoirs contain numerous references to animals. They are usually mentioned in the accounts of wartime escapes and migrations or in the descriptions of requisitions. Animals are depicted as victims of war, but also as creatures participating in the war effort and sharing the suffering of soldiers on the front. In view of prolonged, increasingly severe food shortages they also become an indispensable means of survival for humans. Each of these contexts is discussed in a separate section of the article. Most references in source documents are made to horses, which is due to their usefulness on the front and in the hinterland. Other animals mentioned are cattle, pigs, and poultry. Dogs hardly ever appear in the analyzed diaries, with barely any references to their presence on the front or in the hinterland. Cats are not mentioned at all. The analysis of the source material shows that the relationship between animals and humans was based on rigidly defined rules. Animals were to be useful for people, who in turn took care of them. If they served their purpose right, they would be well looked after by their owners. A new phenomenon, seemingly tied to the outbreak of the war, was the growing significance of animals, as their presence would often be instrumental to the survival of humans. It is also interesting to note that the diaries do not make references to animal abuse or their mistreatment, which could be dictated by the character of the analyzed sources, the background of their authors, etc.

Katarzyna Sierakowska - dr hab., prof. w Instytucie Historii im. Tadeusza Manteuffla Polskiej Akademii Nauk. Zainteresowania badawcze: historia społeczna XIX i XX w., ze szczególnym uwzględnieniem problematyki gender, historii rodziny i doświadczenia okresu I wojny światowej. Autorka książek: Rodzice, dzieci, dziadkowie... Wielkomiejska rodzina inteligencka $w$ Polsce 1918-1939, Warszawa 2003; Śmierć - wygnanie - gtód w dokumentach osobistych. Ziemie polskie w latach Wielkiej Wojny 1914-1918, Warszawa 2015 oraz wielu artykułów. 
Katarzyna Sierakowska - PhD with habilitation, professor at the Tadeusz Manteuffel Institute of History, Polish Academy of Sciences. Academic interests: economic history of the nineteenth and the twentieth century with emphasis on the issues of gender, history of family and the experience of World War I. Author of books: Rodzice, dzieci, dziadkowie... Wielkomiejska rodzina inteligencka $w$ Polsce 1918-1939, Warsaw, 2003; Śmierć - wygnanie - gtód $w$ dokumentach osobistych. Ziemie polskie w latach Wielkiej Wojny 1914-1918, Warsaw, 2015, as well as numerous articles.

E-mail: kasia.sierakowska@interia.pl. 